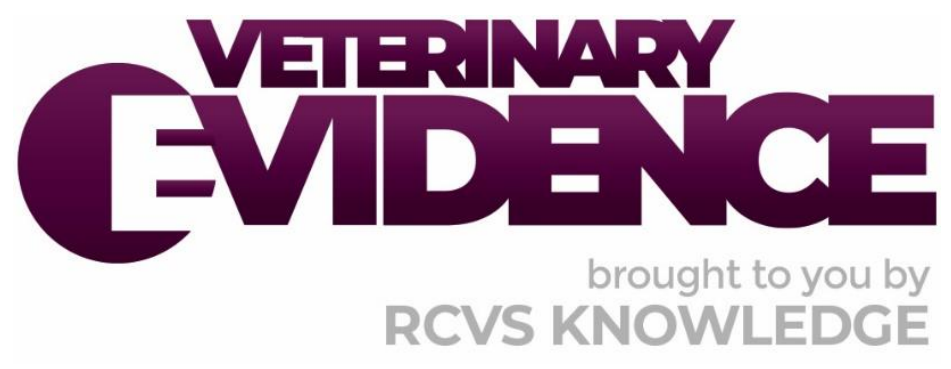

\title{
Grading the evidence and writing the clinical bottom line
}

\section{Editorial}

Peter Cockcroft Editor-in-chief ${ }^{1^{*}}$

\footnotetext{
${ }^{1}$ University of Surrey, School of Veterinary Medicine, Daphne Jackson Rd, Guildford GU2 7AL

*Corresponding Author (p.cockcroft@surrey.ac.uk)
}

ISSN: 2396-9776

Published: 02 Dec 2019

in: Vol 4, Issue 4

DOI: $10.18849 /$ VE.V4I4.305 
The clinical bottom line in a Knowledge Summary provides the reader with a qualified answer to the clinical question posed.

It is important that this section has a consistent format and that the readers are able to understand what the clinical bottom line means and how to interpret the information.

One of the most challenging tasks for authors, whether it be a systematic review or a Knowledge Summary, is grading the body of evidence so that the collective confidence in the study outcomes can be recognised. The strength of evidence provided by a study type is dependent upon the clinical question being addressed as indicated in Table 1. For example a randomised controlled trial potentially provides the strongest evidence when two treatments are compared, whereas a cohort study would be the best for prognosis. It is also dependent upon how well the study was designed and implemented.

The strength of evidence (or the confidence in the outcomes) provided by a study can be deduced from the study type and factors which increase (e.g. large sample size) or reduce (e.g. lack of blinding) the strength of evidence.

These principles are described in the GRADE (Grading of Recommendations, Assessment, Development and Evaluation) system, which is a formal process to rate the quality of scientific evidence in systematic reviews. The details of this system have been described in detail (Balshem et al 2011).

We have now created a clinical bottom line format using sub-headings and have provided new guidelines to authors, which are reproduced below. We have also removed the term 'recommendation' and replaced this with 'conclusion' as the information provided needs to be considered in the context of a specific case in clinical practice. We hope you find this new format and information useful.

\section{Instructions to authors - The Clinical Bottom Line}

The strength of evidence provided by a study type is dependent upon the clinical question being addressed, as indicated in Table 1.

It is also dependent upon how well the study was designed and implemented. Factors to be considered in the study design may include the sample size, bias, blinding, control of variables, appropriate use of statistical tests, the power of the study, the accuracy and precision of any measurements made, the sample population and other components that may reduce the strength of evidence provided by the study.

When composing the clinical bottom line, it is important that the strength of the body of evidence provided by the studies is assessed and categorised according to Table 2 below. The outcomes from the studies should then be clearly stated. Conclusions and additional comments based upon the strength of evidence and the outcomes reported should then be made. 
Table 1: Level of evidence table, adapted from the Oxford Centre for Evidence-Based Medicine's levels of evidence

\begin{tabular}{|c|c|c|c|c|c|c|}
\hline \multirow{2}{*}{$\begin{array}{l}\text { Strength } \\
\text { of } \\
\text { evidence }\end{array}$} & \multicolumn{6}{|c|}{ Clinical question being addressed } \\
\hline & Treatment & Prognosis & Risk & Diagnosis & Prevalence & Incidence \\
\hline $\begin{array}{l}1 \\
\text { (strongest) }\end{array}$ & $\begin{array}{l}\text { Systematic } \\
\text { review and } \\
\text { meta-analysis }\end{array}$ & $\begin{array}{l}\text { Systematic } \\
\text { review and } \\
\text { meta-analysis }\end{array}$ & $\begin{array}{l}\text { Systematic } \\
\text { review and } \\
\text { meta-analysis }\end{array}$ & $\begin{array}{l}\text { Systematic } \\
\text { review and } \\
\text { meta-analysis }\end{array}$ & $\begin{array}{l}\text { Systematic } \\
\text { review and } \\
\text { meta-analysis }\end{array}$ & $\begin{array}{l}\text { Systematic } \\
\text { review and } \\
\text { meta-analysis }\end{array}$ \\
\hline 2 & $\begin{array}{l}\text { Randomised } \\
\text { controlled } \\
\text { trial }\end{array}$ & Cohort study & Cohort study & $\begin{array}{l}\text { Diagnostic test } \\
\text { evaluation } \\
\text { study }\end{array}$ & $\begin{array}{l}\text { Cross- } \\
\text { sectional } \\
\text { study }\end{array}$ & Cohort study \\
\hline 3 & Cohort study & - & $\begin{array}{l}\text { Case-control } \\
\text { study }\end{array}$ & - & - & - \\
\hline 4 & $\begin{array}{l}\text { Case report } \\
\text { or case study }\end{array}$ & $\begin{array}{l}\text { Case report or } \\
\text { case study }\end{array}$ & $\begin{array}{l}\text { Case report or } \\
\text { case study }\end{array}$ & $\begin{array}{l}\text { Case report or } \\
\text { case study }\end{array}$ & $\begin{array}{l}\text { Case report or } \\
\text { case study }\end{array}$ & $\begin{array}{l}\text { Case report or } \\
\text { case study }\end{array}$ \\
\hline $\begin{array}{l}5 \\
\text { (weakest) }\end{array}$ & $\begin{array}{l}\text { Opinion } \\
\text { consensus }\end{array}$ & $\begin{array}{l}\text { Opinion } \\
\text { consensus }\end{array}$ & $\begin{array}{l}\text { Opinion } \\
\text { consensus }\end{array}$ & $\begin{array}{l}\text { Opinion } \\
\text { consensus }\end{array}$ & $\begin{array}{l}\text { Opinion } \\
\text { consensus }\end{array}$ & $\begin{array}{l}\text { Opinion } \\
\text { consensus }\end{array}$ \\
\hline
\end{tabular}

Modified from Rees Gwen (2019)

Table 2: Significance of the four levels of collective evidence used in the clinical bottom line

\begin{tabular}{|l|l|}
\hline $\begin{array}{l}\text { Strength of evidence } \\
\text { provided by the } \\
\text { study designs }\end{array}$ & Definition \\
\hline Strong & $\begin{array}{l}\text { High level of confidence that the estimate of the effect reported by the studies lies } \\
\text { close to the true effect. }\end{array}$ \\
\hline Moderate & $\begin{array}{l}\text { Moderate confidence that the estimate of effect reported by the studies lies close to } \\
\text { the true effect. }\end{array}$ \\
\hline Weak & $\begin{array}{l}\text { Limited confidence that the estimate of effect reported by the studies lies close to the } \\
\text { true effect. Additional appropriate studies are required. }\end{array}$ \\
\hline Zero & No studies available. \\
\hline
\end{tabular}

Modified from Balshem et al (2011)

When writing a Knowledge Summary, authors will be asked to fill in the below section within the submission template: 


\section{Question}

(In PICO format)

Clinical bottom line

- The category of research question was treatment/prognosis/risk/diagnosis/prevalence/incidence Indicate the category of research question that was addressed

- The number and type of study designs that were critically appraised were... Indicate the number and type of study designs which were critically appraised

- Critical appraisal of the selected papers meeting the inclusion criteria collectively provide zero/weak/moderate/strong evidence in terms of their experimental design and implementation. Indicate the strength of evidence

- The outcomes reported are summarised as follows... Indicate the summarised collective outcome(s) from the studies

- In view of the strength of evidence and the outcomes from the studies the following conclusion is made...

The conclusion should provide an answer to the Knowledge Summary question Additional comments and caveats can be added if required

An example using the Knowledge Summary by Natasha A Jocelyn (2018) is provided below.

Figure 2: Example of completed clinical bottom line

\section{Question}

In an Adult Horse With Severe Asthma (Previously Recurrent Airway Obstruction) Does Using Inhaled Corticosteroids Result in an Equal Improvement in Clinical Signs When Compared to Systemic

Corticosteroids?

Clinical bottom line

- The category of research question was treatment/prognosis/risk/diagnosis/prevalence/incidence Treatment.

- The number and type of study designs that were critically appraised were...

Four papers were critically reviewed. There were 3 prospective crossover design clinical studies and a randomised design clinical study.

- Critical appraisal of the selected papers meeting the inclusion criteria collectively provide zero/weak/moderate/strong evidence in terms of their experimental design and implementation. Strong.

- The outcomes reported are summarised as follows.

Inhaled corticosteroids (fluticasone and beclomethasone) when used at an appropriate dose can have equivalent effects on severe equine asthma as systemic intravenous dexamethasone. Inhaled corticosteroids can take longer to have the desired effects.

- In view of the strength of evidence and the outcomes from the studies the following conclusion is made...

In an adult horse with severe asthma (previously recurrent airway obstruction) Inhaled corticosteroids result in an equal Improvement in clinical signs when compared to systemic corticosteroids. 
1. Balshem H, Helfand M, Schünemann HJ, Oxman AD, Kunz R, Brozek J, Vist GE, Falck-Ytter Y, Meerpohl J, Norris S, Guyatt GH. (2011). GRADE guidelines: 3. Rating the quality of evidence J Clin Epidemiol. 2011 Apr;64(4):401-6. doi: https://doi.org/10.1016/i.jclinepi.2010.07.015

2. Jocelyn, N. (2018). In an Adult Horse With Severe Asthma (Previously Recurrent Airway Obstruction) Does Using Inhaled Corticosteroids Result in an Equal Improvement in Clinical Signs When Compared to Systemic Corticosteroids?. Veterinary Evidence, 3(2). doi: http://dx.doi.org/10.18849/ve.v3i2.139

3. Rees Gwen (2019). Addressing the evidence gap: new techniques to solve an old problem Vet. Rec. 184,11, p346-347 doi: http://dx.doi.org/10.1136/vr.1914 


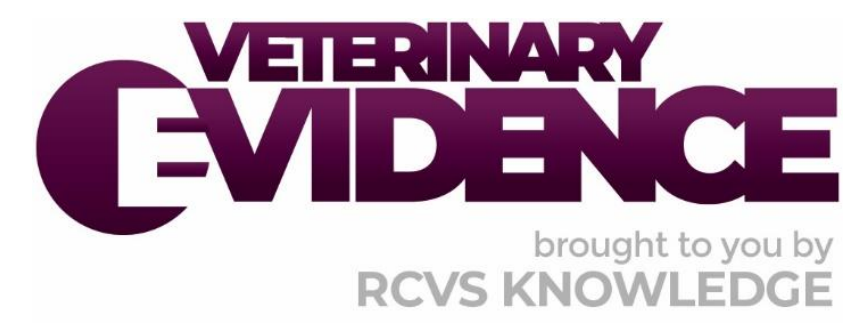

\begin{abstract}
Intellectual Property Rights
Authors of Commentaries submitted to RCVS Knowledge for publication will retain copyright in their work, and will be required to grant to RCVS Knowledge a nonexclusive license of the rights of copyright in the materials including but not limited to the right to publish, re-publish, transmit, sell, distribute and otherwise use the materials in all languages and all media throughout the world, and to license or permit others to do so.

\section{Disclaimer}

Any opinions expressed within the articles published in Veterinary Evidence are the author's own and do not necessarily reflect the view of RCVS Knowledge. Authors are responsible for the accuracy of the content. While the Editor and Publisher believe that all content herein are in accord with current recommendations and practice at the time of publication, they accept no legal responsibility for any errors or omissions, and make no warranty, express or implied, with respect to material contained within. For further information please refer to our Terms of Use.
\end{abstract}

Veterinary Evidence and EBVM Network are RCVS Knowledge initiatives. For more information please contact us at editor@veterinaryevidence.org.

RCVS Knowledge is the independent charity associated with the Royal College of Veterinary Surgeons (RCVS). Our ambition is to become a global intermediary for evidence based veterinary knowledge by providing access to information that is of immediate value to practicing veterinary professionals and directly contributes to evidence based clinical decision-making.

RCVS Knowledge is a registered Charity No. 230886.

Registered as a Company limited by guarantee in England and Wales No. 598443.

Registered Office: Belgravia House, 62-64 Horseferry Road, London SW1P 2AF

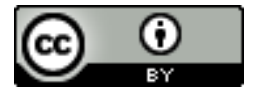

This work is licensed under a Creative Commons Attribution 4.0 International License. 